\title{
Morphogenesis in guinea grass pastures under rotational grazing strategies
}

\author{
Denise Baptaglin Montagner ${ }^{1}$, Domicio do Nascimento Júnior ${ }^{2}$, Braulio Maia de Lana Sousa ${ }^{2}$, \\ Hélio Henrique Vilela ${ }^{2}$, Márcia Cristina Teixeira da Silveira ${ }^{{ }^{*}}$, Valéria Pacheco Batista \\ Euclides $^{1}$, Sila Carneiro da Silva ${ }^{3}$, Marciele Neves Carloto ${ }^{4}$

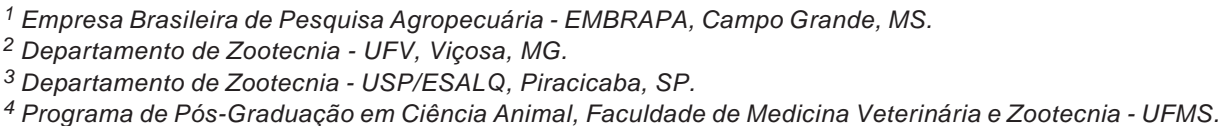

\begin{abstract}
This study was conducted in order to evaluate the morphogenetic and structural characteristics of guinea grass cv. Mombasa under three post-grazing heights (intense - $30 \mathrm{~cm}$, lenient $-50 \mathrm{~cm}$ and variable - 50 in springsummer and $30 \mathrm{~cm}$ in autumn-winter) when sward light interception reached 95\% during regrowth. Post-grazing heights were allocated to experimental units (0.25 ha) in a completely randomized block design with three replications. Postgrazing heights affected only leaf elongation rate and the number of live leaves. Pastures managed with variable postgrazing height showed higher leaf elongation rate in the summer of 2007. This management strategy also resulted in a higher number of live leaves. During the spring of 2006, plants showed lower leaf elongation rate, leaf appearance rate and number of live leaves, and greater phyllochron and leaf lifespan. In contrast, during the summer of 2007, the leaf appearance rate, leaf elongation rate, number of live leaves, and final leaf length were greater while phyllochron, stem elongation rate, and leaf senescence rate were lower. The management of the guinea grass cv. Mombasa with intense or variable post-grazing height throughout the year seems to represent an interesting management target, in terms of leaf appearance rate and number of live leaves.
\end{abstract}

Key Words: ecophysiology, grazing management, light interception, Panicum maximum cv. Mombasa, post-grazing height

\section{Introduction}

The use of morphogenesis to study growth and development of plants in sward allows for a better understanding of dynamics responses of the sward to defoliation (Silveira et al., 2010; Sousa et al., 2010, 2011). In adequate environmental conditions (photoperiod, temperature, humidity and soil fertility), the plants accelerate their growth rhythm, increasing their leaf appearance and elongation rates (Marcelino et al., 2006) and their stem elongation rate (Mazzanti et al., 1994; Difante et al., 2008). Therefore, the forage accumulation in the beginning of the regrowth is composed basically of leaves (Da Silva \& Nascimento Júnior, 2007). As the plant grows, the intraspecific competition for light increases progressively; the stem elongation, the leaf senescence rate, and the death of the tillers intensify while the leaf accumulation decreases (Carnevalli et al., 2006; Barbosa et al., 2007). These morphophisiological changes occur after $95 \%$ interception of light by the sward, a fact that has been characterizing this point with the ideal moment to interrupt the regrowth (Da Silva \& Nascimento Júnior, 2007; Da Silva et al., 2009).
Once the defoliation frequency is defined, the pasture management flexibility can be generated by the variations in the post-grazing height used. When grazing conditions are kept relatively constant throughout the year, intense grazing promotes high potential for tissue renewal, with high accumulation of leaf and effective control of stem accumulation. Lenient grazing results in higher accumulation of stem, but greater pasture utilization often promotes quicker growth of forage plants (Difante et al., 2009a,b). Variation in grazing intensity throughout the year may be an alternative approach to increase pasture utilization during the spring and the summer and to control stem accumulation during autumn and winter.

Therefore, the objective of this research was to measure the effects of varying grazing intensity on the morphogenetic and structural characteristics of Panicum maximum cv. Mombasa under rotational stocking.

\section{Material and Methods}

The experiment was carried from September 2005 to April 2007, in guinea grass (Panicum maximum cv. 
Mombasa) pastures of 2.25 ha, in Campo Grande, MS, Brazil ( $20^{\circ} 27^{\prime} \mathrm{S} ; 54^{\circ} 37^{\prime} \mathrm{W}$; $\left.530 \mathrm{~m}\right)$. According to the Köppen classification, the climate is tropical wet, subtype Aw, with well-defined dry (May to September) and rainy (October to April) periods. The climate data (Figure 1) were obtained from a meteorological station approximately $4 \mathrm{~km}$ away from the experimental area. The monthly extract of soil water balance related during the experimental period (Figure 2) was calculated using $50 \mathrm{~mm}$ water storage capacity (Thornthwaite \& Mather, 1955).

The local soil is classified as dystrophic red latosol (EMBRAPA, 1999) of argillaceous texture, acid pH, low base saturation and high aluminum concentration. Results from chemical analysis of soil (Raij et al., 1986) for the 0-20 cm layer were: $\mathrm{pH}$ in $\mathrm{H}_{2} \mathrm{O}=5.05 ; \mathrm{P}=2.03$ (Mehlich-1) and $\mathrm{K}=151 \mathrm{mg} / \mathrm{dm}^{3} ; \mathrm{Ca}=1.95 ; \mathrm{Mg}=1.25 ; \mathrm{Al}=0.03$; $\mathrm{H}+\mathrm{Al}=3.81$ and cation exchange capacity $=35.9 \mathrm{mmol}_{c} / \mathrm{dm}^{3}$; base saturation $=48.5 \%$.

The pastures were established in February 2004 through the seeding of $2 \mathrm{~kg} / \mathrm{ha}$ of pure viable seeds, using $3,700 \mathrm{~kg} / \mathrm{ha}$ of dolomitic limestone, $500 \mathrm{~kg} / \mathrm{ha}$ of the 0-20-15 ratio, and $50 \mathrm{~kg} / \mathrm{ha}$ of FTE BR-12. Thereafter, the

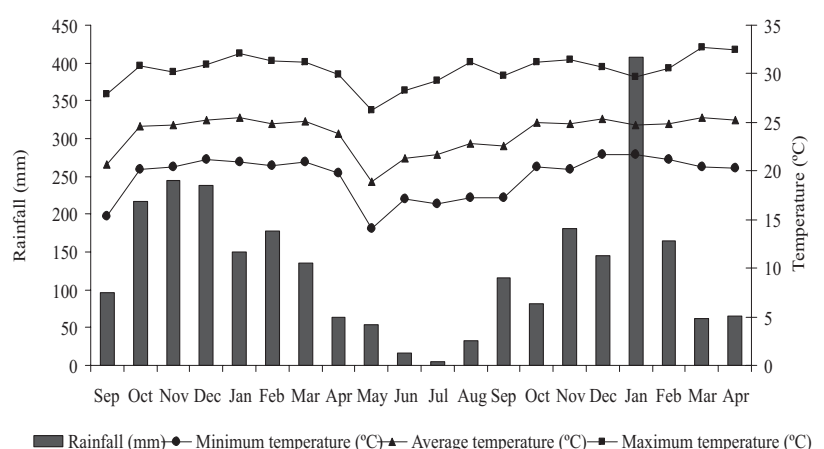

Figure 1 - Monthly rainfall, and minimum, mean and maximum temperatures during the experiment (September 2005 to April 2007), in Campo Grande, MS.

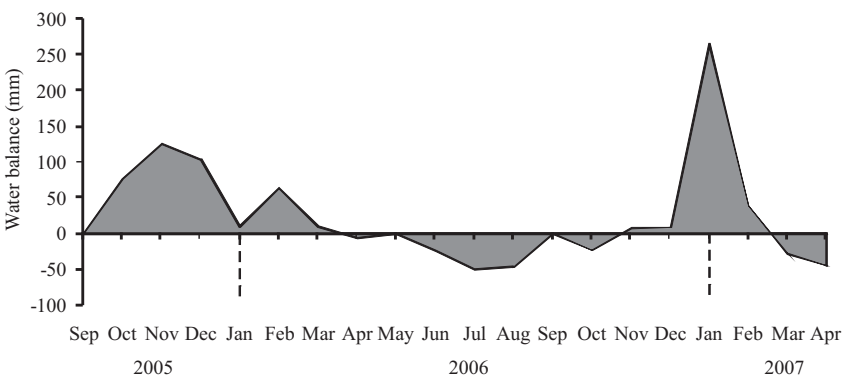

Figure 2 - Monthly water balance during the experimental period from September 2005 to April 2007, in Campo Grande, MS. pastures were grazed. In October 2004, 1,000 kg/ha of dolomitic limestone were applied as well as $8,000 \mathrm{~kg} / \mathrm{ha}$ of agricultural plaster. In November 2005 and October 2006, $400 \mathrm{~kg} / \mathrm{ha}$ of NPK (ratio 0-20-20) and $200 \mathrm{~kg} / \mathrm{ha}$ of nitrogen in the form of urea were applied. Nitrogen was applied after the grazing of each paddock, during the rainy season. The last nitrogen application was done on 02/14/2007 and the grazing until April 2007.

Three intensities of pasture were assessed, characterized by the height of residues post-grazing: the most intense post-grazing height $(30 \mathrm{~cm})$ aimed to maximize the use of the forage produced; the most lenient post-grazing height $(50 \mathrm{~cm})$, usually used in management procedures of this grass in production systems, aims to generate higher individual performance of animals; and the variable height post-grazing ( $50 \mathrm{~cm}$ of residue in spring/summer, lowered to $40 \mathrm{~cm}$ in the first grazing of the autumn and $30 \mathrm{~cm}$ in the following grazing, returning to $50 \mathrm{~cm}$ after the first grazing of the spring) aims to obtain greater pasture growth and individual animal performance in the spring and summer and reduction of stem accumulation and senescent leaves in the autumn and winter.

Grazing was initiated when the sward reached 95\% light interception during regrowth. The post-grazing heights were allocated to 0.25 ha experimental units in a completely randomized block design with three replications. Grazing was performed using the "mob grazing" method (Mislevy et al., 1983) by young males (18 months old) with approximately $310 \mathrm{~kg}$ of body weight.

The monitoring of light interception was done using the sward analyzer AccuPAR Linear PAR/LAI ceptometer, Model PAR 80 (DECAGON Devices) in 30 points per paddock, in W-shaped trajectories (representative locations of the average conditions of the pasture during the sampling. Two readings were taken in each point: one above the sward and another at the soil surface (below the sward). Sward height was measured concomitantly with light interception, following the same trajectory in $\mathrm{W}$, using a ruler, and 40 readings were taken in each experimental unit. The average of the experimental unit was considered the average of these 40 measurements.

At the beginning of each regrowth period, ten tillers were marked, in representative locations of the average condition of the sward, in each experimental unit to evaluate the morphogenetic and structural characteristics. In these tillers, assessments on leaf elongation rate, stubbles and senescence were carried out twice a week throughout the experimental period. The expanded leaf length was measured from its tip to the ligule. In the case of expanding leaves, the same procedure was adopted; however, the ligule of the last 
expanded leaf was used as reference for its measurement. For senescent leaves, the length corresponded to the distance between the ligule and the point where the senescence process advanced. The stubble length was measured using as reference the ligule height of the youngest leaf thoroughly expanded in relation to the soil. The number of live leaves was determined by the sum of expanding and expanded leaves per tiller, excluding leaves that presented more than $50 \%$ of their length already senescent, once they were considered dead. The data were used to calculate the following variables: leaf appearance rate, which is the number of leaves appearing per tiller divided by the number of days of the evaluation period (leaves/tiller.day); leaf elongation rate, which is the sum of all leaf elongation per tiller divided by the number of days of the evaluation period (cm/tiller.day); leaf senescence rate, which is the relation between the sum of senescent lengths of leaves found in the tillers divided by the number of days of the evaluation period ( $\mathrm{cm} /$ tiller.day); stem elongation rate, which is the sum of all stubble elongations per tiller divided by the number of days of the evaluation period (cm/tiller.day); final leaf length, which is the average length of all the leaves of the tiller, measured from the leaf apex to the ligule $(\mathrm{cm})$, number of live leaves per tiller, which is the average number of expanding and expanded leaves per tiller during the experimental period (leaves/tiller); phyllochron, which is the opposite of leaf appearance rate (days/leaf); and leaf lifespan, estimated by the equation proposed by Lemaire \& Chapman (1996), in which leaf lifespan (days/leaf) = number of live leaves $\times$ phyllochron.

The data were grouped according to the seasons of the year. Due to the rotational stocking system in each treatment and repetition, a visual analysis was carried out aiming to identify the seasons of the year in which the standards of the variables studied were relatively homogeneous; however, they represented changes potentially important in the response standard throughout the experimental period.
Therefore, data were grouped into five seasons: spring 2005 (September to December 2005); summer 2006 (January to March 2006); autumn 2006 (April to June 2006); spring 2006 (July to December 2006) and summer 2007 (January to March 2007). The grouped data were analyzed according to a split-plot arrangement, where the grazing treatments were the main plots and the seasons were the subplots. Analysis of variance of the weighted averages by season did not detect heterogeneity of the averages. Therefore, the ANOVA was conducted using the GLM procedure of the statistical package SAS (Statistical Analysis System, version 6.0), where the RANDOM and TEST commands were used. The comparison of averages was done with the Tukey test, adopting a 5\% significance level.

\section{Results}

There was interaction between post-grazing height and the season for leaf elongation rate $(\mathrm{P}<0.05)$ (Table 1$)$. In the summer of 2007, pastures managed with intense and variable post-grazing height had greater leaf elongation rate. In the spring of 2006, leaf elongation rate was lower, regardless of the post-grazing height. Intermediate leaf elongation rate was observed in the other seasons.

Table 1 - Leaf elongation rate (cm/tiller.day) in guinea grass pastures subjected to post-heights when they reach $95 \%$ of light interception during regrowth

\begin{tabular}{lccc}
\hline Season & \multicolumn{3}{c}{ Post-grazing height } \\
\cline { 2 - 4 } & Intense & Lenient & Variable \\
\hline Spring 2005 & $2.05 \mathrm{BCa}$ & $2.88 \mathrm{ABa}$ & $3.14 \mathrm{BCa}$ \\
Summer 2006 & $3.65 \mathrm{Ba}$ & $2.77 \mathrm{ABa}$ & $2.75 \mathrm{BCa}$ \\
Autumn 2006 & $2.87 \mathrm{BCa}$ & $2.63 \mathrm{ABa}$ & $3.25 \mathrm{Ba}$ \\
Spring 2006 & $0.49 \mathrm{Ca}$ & $0.55 \mathrm{Ba}$ & $0.53 \mathrm{Ca}$ \\
Summer 2007 & $7.47 \mathrm{Aa}$ & $4.03 \mathrm{Ab}$ & $6.38 \mathrm{Aa}$
\end{tabular}

Means followed by the same uppercase letter in a column and lowercase letter in a row are not different $(\mathrm{P}>0.05)$ by Tukey test.

Standard error of the mean $=0.5$.

Table 2 - Leaf appearance rate, stem elongation rate, phyllochron, and leaf lifespan in guinea grass pastures in different seasons of the year

\begin{tabular}{|c|c|c|c|c|}
\hline \multirow[t]{2}{*}{ Seasons } & \multicolumn{4}{|c|}{ Characteristics } \\
\hline & $\begin{array}{c}\text { Leaf appearance rate } \\
\text { (leaves/tiller.day) }\end{array}$ & $\begin{array}{c}\text { Stem elongation rate } \\
(\mathrm{cm} / \text { tiller.day })\end{array}$ & $\begin{array}{c}\text { Phyllochron } \\
\text { (days) }\end{array}$ & $\begin{array}{c}\text { Leaf lifespan } \\
\text { (days/leaf) }\end{array}$ \\
\hline Spring 2005 & $0.048 \mathrm{~B}$ & $0.067 \mathrm{~A}$ & $22 \mathrm{~B}$ & $82 \mathrm{~B}$ \\
\hline Summer 2006 & $0.063 \mathrm{~B}$ & $0.040 \mathrm{~A}$ & $18 \mathrm{~B}$ & $75 B$ \\
\hline Autumn 2006 & $0.062 \mathrm{~B}$ & $0.038 \mathrm{~A}$ & 17B & $78 \mathrm{~B}$ \\
\hline Spring 2006 & $0.012 \mathrm{C}$ & $0.048 \mathrm{~A}$ & $88 \mathrm{~A}$ & $247 \mathrm{~A}$ \\
\hline Summer 2007 & $0.097 \mathrm{~A}$ & $0.003 \mathrm{~B}$ & $11 \mathrm{~B}$ & $57 \mathrm{~B}$ \\
\hline SEM & 0.010 & 0.015 & 5.6 & 16.6 \\
\hline
\end{tabular}

Means followed by the same uppercase letter in the column are not different $(\mathrm{P}>0.05)$ by Tukey test. SEM- standard error of the mean. 
Table 3 - Number of live leaves, final leaf length, and leaf senescence rate guinea grass pastures in different seasons of the year

\begin{tabular}{lccc}
\hline \multirow{2}{*}{ Seasons } & \multicolumn{2}{c}{ Characteristics } \\
\cline { 2 - 4 } & Number of live leaves (leaves/tiller) & Final leaf length (cm/leaf) & Leaf senescence rate (cm/tiller.day) \\
\hline Spring 2005 & $3.9 B C$ & $35.8 \mathrm{AB}$ & $1.7 \mathrm{~A}$ \\
Summer 2006 & $4.4 \mathrm{~B}$ & $27.8 \mathrm{C}$ & $1.5 \mathrm{AB}$ \\
Autumn 2006 & $4.7 \mathrm{AB}$ & $27.9 \mathrm{C}$ & $1.3 \mathrm{AB}$ \\
Spring 2006 & $2.8 \mathrm{C}$ & $31.3 \mathrm{BC}$ & $0.9 \mathrm{BC}$ \\
Summer 2007 & $5.4 \mathrm{~A}$ & $39.1 \mathrm{~A}$ & $0.4 \mathrm{C}$ \\
SEM & 0.1 & 1.4 & 0.1 \\
\hline
\end{tabular}

Means followed by the same uppercase letter in the column are not different $(\mathrm{P}>0.05)$ by Tukey test. SEM - standard error of the mean.

The leaf appearance rate, stem elongation rate, phyllochron, and leaf lifespan were only affected by the season $(\mathrm{P}<0.05)$ (Table 2). In the summer of 2007, leaf appearance rate was the greatest and stem elongation rate was the lowest. In the spring of 2006, leaf appearance rate was the lowest, while phyllochron and leaf lifespan were the greatest.

The number of live leaves was affected by the season and post-grazing height $(\mathrm{P}<0.05)$. Pastures managed with variable post-grazing height showed 4.5 live leaves, while pastures kept with lenient and intense post-grazing height showed 4.1 or 4.0 live leaves per tiller (standard error of the mean $=0.2$ ), respectively. The highest was obtained in the summer of 2007 and the smallest in the spring of 2006 (Table 3).

The final leaf length and the leaf senescence rate were influenced only by the season $(\mathrm{P}<0.05)$ (Table 3$)$. In the summer of 2007, leaves were the longest, while in the summer of 2006 and autumn of 2006, they were the shortest. The spring of 2005, the summer of 2006, and the autumn of 2006 showed the highest values of leaf senescence rate, while the summer of 2007 showed the lowest.

\section{Discussion}

The post-grazing height did not affect the leaf appearance rate, the stem elongation rate, the phyllochron, the leaf lifespan, the final leaf length, the number of live leaves by tiller, or the leaf senescence rate of guinea grass cv. Mombasa pastures $(\mathrm{P}>0.05)$. Plant responses to defoliation should be understood as mechanisms for reestablishment and maintenance of the growth patterns, where all the available factors are used for the formation of new photosynthesizing tissues (Lemaire \& Chapman, 1996). Throughout the regrowth period, the competition for light progressively increases, reducing the amount and changing the quality of the light reaching the interior of the sward, determining morphological and physiological changes in the plants. In this experiment, the criterion for determining the beginning of grazing was the same in all treatments, i.e., 95\% light interception, which does not characterize a condition of intense competition for light, may justify the absence of differences in leaf appearance rate, phyllochron, leaf lifespan, final leaf length, and leaf senescence rate in all post-grazing heights. Studies based on growth and development rates of the plants when $95 \%$ of light interception was used do not show differences between the intensities of defoliation tested for the Andropogon grass (Sousa et al., 2010) and Xaraes palisadegrass (Sousa et al., 2011). This shows that the post-grazing heights adopted were adequate for the guinea grass cv. Mombasa, without affecting its remaining leaf area and organic reserves. However, more research is needed to define the critical defoliation targets and intensity defoliation for the guinea grass cv. Mombasa.

Pastures managed with lenient post-grazing height presented lower leaf elongation rate in the 2007 summer in relation to the ones managed with intense and variable post-grazing height. Intense grazing removes higher forage quantity and promotes higher pasture utilization (Carnevalli et al., 2006). When done in the autumn-winter, this practice results in lower quantity of forage for the senescence and death in these seasons. The lower presence of dead material increases the light penetration into the sward, which furthers regrowth in the following season. Hence, the higher quantity and quality of light inside the sward accelerate the leaf elongation (Robson, 1981). Additionally, the higher penetration of light may stimulate tillering, generating a population of younger tillers and with higher growth rate (Langer, 1972). On the other hand, the bigger amount of organic matter found at greater post-grazing heights $(50 \mathrm{~cm})$ minimized the light interception, decreasing the induction of basal buds, and therefore, the tillering of the plant, which determined an older population of tillers with lower growth capacity. This leaf elongation rate increase for intense and variable post-grazing height can result in higher forage production, once this morphogenetic characteristic particularly most relates to forage yield (Horst et al., 1978) and tiller emergence (Nelson et al., 1977). The present results are supported by the results of Brougham (1959, 1960), whose management procedures adopted in one 
season affected the forage yield in the subsequent ones. However, further research with Panicum maximum is needed to corroborate these patterns.

Pastures managed with variable post-grazing heights had a higher number of live leaves (4.5 leaves/tiller) than pastures grazed with intense (4.1 leaves/tiller) or variable (4.0 leaves/tiller) post-grazing height throughout the year. The number of live leaves of a species is genetically determined assuming a value relatively constant (Davies, 1988), but subject to variations in terms of environment and pasture management (Lemaire \& Chapman, 1996). Once final leaf length did not vary in the post-grazing heights, the higher number of live leaves represents a greater participation of leaf in the sward leading to higher regrowth of guinea grass $\mathrm{cv}$. Mombasa under rotational stocking. The leaf is the morphologic component of highest nutritional values (Van Soest, 1994), which can positively affect the performance of the animal.

The morphogenetic and structural characteristics are regulated, mainly, by environmental conditions such as luminosity, water availability, temperature and nitrogen diet (Lemaire and Chapman, 1996; Lemaire and Agnusdei, 2000). Certainly, the changes that occur in these factors between the summers of 2006 and 2007 and between the springs of 2005 and 2006, determined the differences observed in the morphogenetic and structural characteristics. The spring of 2006 (July to December) was characterized by reduced temperature and rainfall (Figures 1 and 2), which resulted in lower leaf elongation rate, leaf appearance rate, and number of live leaves, and greater phyllochron and leaf lifespan (Tables 2 and 3). The hydric stress reduces carbon absorption by limiting gas exchanges at the moment of the closing of stomata (Lemaire, 2001), affecting in the process, nutrient absorption, mainly nitrogen, (Taiz \& Zeiger, 2009) which reduces leaf elongation rate, leaf appearance rate and number of live leaves. When the availability of growth resources decreases, the plant preserves its reserves (Navas et al., 2003). Thus, the plant reduces the appearance and elongation of leaves. The greater leaf lifespan in this period suggests adaptation of the plant by maintaining its leaf area for a longer time, since long-lived leaves contribute to the conservation of nutrients in times of limited availability of resources (Navas et al., 2003).

During the summer of 2007, there was greater leaf appearance rate, leaf elongation rate, number of live leaves, and final leaf length and smaller phyllochron, stem elongation rate, and leaf senescence rate (Tables 2 and 3), indicating high tissue renewal in the pastures in times of high availability of growth factors. According to Lemaire \& Agnusdei (2000), the production of leaf tissue results from the interaction of photosynthesized nutrients by the plant and their use by the foliar meristems in the production of new cells and foliar expansion. The use of photosynthesized nutrients by the foliar meristems is regulated by the temperature (Ben Haj Salah \& Tardieu, 1995). and when variations positive of temperature are sensed by the apical meristem, there is increase in the leaf elongation rate (Peacock, 1975). Duru \& Ducrocq(2000) observed significant increases in leaf appearance rate and in the number of leaves with changes in the temperature, which indicates that this environmental factor is one of the most important in leaf appearance rate control (Bauer et al., 1984).

The guinea grass cv. Mombasa, during the spring of 2006, showed lower leaf elongation rate, leaf appearance rate, phyllochron, number of live leaves and final leaf length and higher leaf lifespan and leaf senescence rate in relation to the spring of 2005. The pastures managed in the summer of 2007 presented higher leaf elongation rate, leaf appearance rate, number of live leaves and final leaf length and lower stem elongation rate and leaf senescence rate in comparison with the summer of 2006. Even within the same season, the growth conditions varied from one year to another (Figures 1 and 2).

For a long time, the pastures used in this experiment were managed through fixed intervals of a grazing system (days), i.e., without the control of the sward structure (Hodgson, 1990). Such a system disregards growth and development rates of forage and plant morphology, leading to high senescence rates, as in the spring of 2005 (Table 3). The control of the sward structure of these pastures, starting in the spring 2005, generated a reduction in leaf senescence and death rates (Table 3). Therefore, the adoption of these types of management, in which defoliation cycles are set strategically and based on morphophysiology rather than a fixed interval of time, reduces senescence and death of leaves.

\section{Conclusions}

The lowering of the post-grazing height from $50 \mathrm{~cm}$ to $30 \mathrm{~cm}$ in the autumn, returning to $50 \mathrm{~cm}$ after the first grazing in the spring, appears to be promising, allowing greater leaf elongation rate and number of live leaves in the following summer.

\section{References}

BARBOSA, R.A.; NASCIMENTO JÚNIOR, D.; EUCLIDES, V.B.P. et al. Capim-tanzânia submetido a combinações entre intensidade e frequência de pastejo. Pesquisa Agropecuária Brasileira, v.42, p.329-340, 2007. 
BAUER, A.; FRANK, A.B.; BLACK, A.L. Estimation of spring wheat leaf growth rates from air temperature. Agronomy Journal, v.76, p.829-835, 1984.

BEN HAJ SALAH, H.; TARDIEU, F. Temperature affects expansion rate of maize leaves without change in spatial distribution of cell length. Plant Phisiology, v.109, p.861-870, 1995.

BROUGHAM, R.W. The effects of frequency and intensity of grazing on the productivity of a pasture of short-rotation ryegrass and red and white clover. New Zealand Journal of Agricultural Research, v.2, p.232-1248, 1959.

BROUGHAM, R.W. The effects of frequent hard grazing at different times of the year on the productivity and species yields of a grassclover pastures. New Zealand Journal of Agricultural Research, v.3, p.125-136, 1960.

CARNEVALLI, R.A.; DA SILVA, S.C.; BUENO, A.A.O. et al. Herbage production and grazing losses in Panicum maximum cv. Mombasa under four grazing managements. Tropical Grasslands, v.40, p.165-176, 2006.

DA SILVA, S.C.; BUENO, A.A.O.; CARNEVALLI, R.A. et al. Sward structural characteristics and herbage accumulation of Panicum maximum cv. Mombaça subjected to rotational stocking managements. Scientia Agricola, v.66, p.8-19, 2009.

DA SILVA, S.C.; NASCIMENTO JÚNIOR, D. Avanços na pesquisa com plantas forrageiras tropicais em pastagens: características morfofisiológicas e manejo do pastejo. Revista Brasileira de Zootecnia, v.36, p.121-138, 2007 (supl. especial).

DAVIES, A. The regrowth of grass swards. In: JONES M.B.; LAZEMBY A. (Eds.). The grass crop: The physiological basis of production. London: Chapman and Hall, 1988. p.85-127.

DIFANTE, G.S.; NASCIMENTO JÚNIOR, D.; DA SILVA, S.C. et al. Dinâmica do perfilhamento do capim-marandu cultivado em duas alturas e três intervalos de corte. Revista Brasileira de Zootecnia, v.37, n.2, p.189-196, 2008.

DIFANTE, G.S.; NASCIMENTO JÚNIOR, D.; EUCLIDES, V.P.B. et al. Sward structure and nutritive value of tanzania guineagrass subjected to rotational stocking managements. Revista Brasileira de Zootecnia, v.38, n.1, p.9-19, 2009a.

DIFANTE, G.S.; EUCLIDES, V.P.B.; NASCIMENTO JÚNIOR, D. et al. Ingestive behavior, herbage intake and grazing efficiency of beef cattle steers on Tanzania guineagrass subjected to rotational stocking managements. Revista Brasileira de Zootecnia, v.38, n.6, p.1001-1008, 2009b.

DURU, M; DUCROCQ, H. Growth and senescence of the successive grass leaves o a tiller ontogenic development and effect of temperature. Annals of Botany, v.85, p.635-643, 2000.

EMPRESA BRASILEIRA DE PESQUISA AGROPECUÁRIA EMBRAPA. Serviço Nacional de Levantamento e Conservação de Solos. Sistema brasileiro de classificação de solos. Brasília: Embrapa Produção e Informação, 1999. 412p.

HODGSON, J. Grazing management: science into practice. New York: Longman, 1990. 203p.

HORST, G.L.; NELSON, C.J.; ASAY, K.H. Relationship of leaf elongation to forage yield of tall fescue genotypes. Crop Science, v.18, p.715-719, 1978.

LANGER, R.H.M. How grasses grow. London: Edward Arnold. 1972. 60p. (Studies in Biology, 34).

LEMAIRE, G. Ecophysiology of grasslands: dynamic aspects of forage plant populations in grazed swards. In: INTERNATIONAL GRASSLAND CONGRESS 19., 2001, São Pedro. Proceedings... São Pedro: FEALQ, 2001. p.29-37.
LEMAIRE, G.; AGNUSDEI, M. Leaf tissue turn-over and efficiency of herbage utilization. In: LEMAIRE, G.; HODGSON, J.; MORAES, A. et al. (Eds.). Grassland ecophysiology and grazing ecology. Wallingford: CAB International, 2000. p.265-288.

LEMAIRE, G.; CHAPMAN, D. Tissue flows in grazed plant communities. In: HODGSON, J.; ILLIUS, A.W. (Eds.). The ecology and management of grazing systems. Wallingford: CAB International, 1996. p.3-36.

MARCELINO, K.R.A.; NASCIMENTO JÚNIOR, D.; DA SILVA, S.C. et al. Características morfogênicas e estruturais e produção de forragem do capim-marandu submetido a intensidades $e$ frequências de desfolhação. Revista Brasileira de Zootecnia, v.35, n.6, p.2243-2252, 2006.

MAZZANTI, A.; LEMAIRE, G.; GASTAL, F. The effect of nitrogen fertilization upon herbage production of tall fescue swards grazed by shepp. 1. Herbage growth dynamics. Grass and Forage Science, v.49, p.111-120, 1994.

MESQUITA, P.; DA SILVA, S.C.; PAIVA, A.J. et al. Structural characteristics of marandu palisadegrass swards subjected to continuous stocking and contrasting rhythms of growth. Scientia Agricola, v.67, n.1, p.23-30, 2010.

MISLEVY, P.; MOTT, G.O.; MARTIN, F.G. Screening perennial forages by mob-grazing technique. In: INTERNATIONAL GRASSLAND CONGRESS, 14., 1983, Lexington. Proceedings.. Boulder: Westview Press, 1983. p.516-519.

NAVAS, M.L.; DUCOUT, B.; ROURNET, C. et al. Leaf lifespan, dynamics and construction cost of species from Mediterranean old-fields differing in successional status. New Phytologist, v.159, p.213-228, 2003.

NELSON, C.J.; ASAY, K.H.; SLEPER, D.A. Mechanisms of canopy development of tall fescue genotypes. Crop Science, v.17, p.449-452, 1977

PEACOCK, J.M. Temperature and leaf growth in Lolium perene. 1. The thermal microclimate: its measurement and relation to plant growth. Journal of Applied Ecology, v.12, p.115-123, 1975.

RAIJ, B.V.; QUAGGIO, J.A.; SILVA, N.M. Extraction of phosphorus, potassium, calcium, and magnesium from soils by ion-exchange resin procedure. Communications in Soil Science and Plant Analysis, v.17, n.5, p.547-566, 1986.

ROBSON, M.J. Potential production - what is it and can we increase it?. In: OCCASIONAL SYMPOSIUM - PLANT PHYSIOLOGY AND HERBAGE PRODUCTION, 13., 1981, England. Proceedings... England: British Grassland Society, 1981. p.5-17.

SILVEIRA, M.C.T.; NASCIMENTO JÚNIOR, D.; DA SILVA, S.C. et al. Morphogenetic and structural comparative characterization of tropical forage grass cultivars under free growth. Scientia Agricola, v.67, p.136-142, 2010.

SOUSA, B.M.L.; NASCIMENTO JÚNIOR, D.; DA SILVA, S.C. et al. Morphogenetic and structural characteristics of Andropogon grass submitted to different cutting heights. Revista Brasileira de Zootecnia, v.39, p.2141-2147, 2010.

SOUSA, B.M.L.; NASCIMENTO JÚNIOR, D.; RODRIGUES, C.S. et al. Morphogenetic and structural characteristics of Xaraes palisadegrass submitted to cutting heights. Revista Brasileira de Zootecnia, v.40, p.53-59, 2011.

TAIZ, L.; ZEIGER, E. Fisiologia vegetal. 4.ed. Porto Alegre: Artmed, 2009. 819p.

THORNTHWAITE, C.W.; MATHER, R.J. The water balance. New Jersey: Laboratory of Climatology, v.8, 1955. 104p.

VAN SOEST, P.J. Nutritional ecology of the ruminant. 2.ed. New York: Cornell University Press, 1994. 476p. 